\title{
Tulane
}

\author{
Tulane Economics Working Paper Series
}

\section{Social Spending and Income Redistribution in Argentina During the 2000s: the Rising Role of Noncontributory Pensions}

\author{
Nora Lustig, Coordinator Carola Pessino, Argentina
}

Working Paper 1221

November 2012

\begin{abstract}
Between 2003 and 2009, Argentinas social spending as a share of GDP increased by 7.6 percentage points. Marginal benefit incidence analysis for 2003, 2006, and 2009 suggests that the contribution of cash transfers to the reduction of disposable income inequality and poverty rose markedly between 2006 and 2009 primarily due to the launching of a noncontributory pension program the pension moratorium in 2004. Noncontributory pensions as a share of GDP rose by 2.2 percentage points between 2003 and 2009 and entailed a redistribution of income to the poor, and from the formal sector pensioners with above minimum pensions to the beneficiaries of the pension moratorium. The redistributive impact of the expansion of public spending on education and health was also sizeable and equalizing, but to a lesser degree. An assessment of fiscal funding sources puts the sustainability of the redistributive policies into question, unless nonsocial spending is significantly cut.
\end{abstract}

Keywords: social spending, benefit incidence, inequality, poverty, Argentina JEL: Keywords: D31, H22, I38 


\section{Glomammax TO EQUITY}

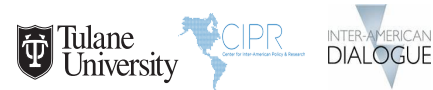 \\ Social Spending and Income Redistribution in Argentina During the 2000s: the Rising Role of Noncontributory Pensions. Extended Version ${ }^{1}$}

Nora Lustig and Carola Pessino ${ }^{2}$

November 20, 2012

Working Paper

\footnotetext{
${ }^{1}$ This paper is an extended version of Lustig and Pessino (2012). This paper is an output of the Commitment to Equity Project (CEQ). Led by Nora Lustig (Tulane University) and Peter Hakim (Inter-American Dialogue), CEQ) is a joint project of the Inter-American Dialogue (IAD) and Tulane University's Center for Inter-American Policy and Research (CIPR) and Department of Economics. The project has received financial support from the Canadian International Development Agency (CIDA), the Development Bank of Latin America (CAF), the General Electric Foundation, the Inter-American Development Bank (IADB), the International Fund for Agricultural Development (IFAD), the Norwegian Ministry of Foreign Affairs, the United Nations Development Programme's Regional Bureau for Latin America and the Caribbean (UNDP/RBLAC), and the World Bank. http://commitmenttoequity.org

2 Nora Lustig is Samuel Z. Stone Professor of Latin American Economics, Tulane University (Department of Economics; Stone Center for Latin American Studies and CIPR); nonresident fellow, Center for Global Development and Inter-American Dialogue. Carola Pessino is Senior Researcher, Department of Economics at the Universidad del CEMA, Argentina and Visiting Fellow of the Center for Global Development, Washington, DC. The authors are very grateful to Emily Travis for excellent research assistantship.
} 


\begin{abstract}
Between 2003 and 2009, Argentina's social spending as a share of GDP increased by 7.6 percentage points. Marginal benefit incidence analysis for 2003, 2006, and 2009 suggests that the contribution of cash transfers to the reduction of disposable income inequality and poverty rose markedly between 2006 and 2009 primarily due to the launching of a noncontributory pension program - the pension moratorium - in 2004. Noncontributory pensions as a share of GDP rose by 2.2 percentage points between 2003 and 2009 and entailed a redistribution of income to the poor, and from the formal sector pensioners with above minimum pensions to the beneficiaries of the pension moratorium. The redistributive impact of the expansion of public spending on education and health was also sizeable and equalizing, but to a lesser degree. An assessment of fiscal funding sources puts the sustainability of the redistributive policies into question, unless nonsocial spending is significantly cut.
\end{abstract}

Keywords: social spending, benefit incidence, inequality, poverty, Argentina JEL Codes: D31, H22, I38 


\section{INTRODUCTION}

Between 2003 and 2009, Argentina's primary government spending ${ }^{3}$ grew by 13.5 percentage points to reach 40.6 percent of GDP. Social spending accounts for about 56 percent of the increase, nonsocial spending for about 37 percent, and contributory pensions for about 7 percent. Within social spending, the increase is roughly evenly distributed among noncontributory pensions, government spending on education and health, and other social spending (table 1).

What has been the redistributive impact of such an extraordinary expansion of government spending? Using the Encuesta Permanente de Hogares ${ }^{4}$ for 2003, 2006, and 2009 - hereafter EPH - we apply standard benefit incidence analysis to analyze the impact of social spending on inequality and poverty and how the impact has changed. We estimate the effects under a benchmark scenario in which contributory pensions are included under market income and a sensitivity analysis in which they are considered a government transfer. We include a brief description of how the expansion in public spending has been financed and discuss whether it is sustainable. We do not incorporate behavioral, life-cycle, or general equilibrium effects. In spite of these limitations, however, this study is one of the most thorough incidence analyses for Argentina's social spending for the period considered. ${ }^{5}$ Furthermore, because we do the incidence analysis for three years, we are able to assess the marginal effects of the changes in social policy introduced during this period.

The paper is organized as follows. Section 2 presents a summary of Argentina's social and nonsocial spending. Section 3 presents the data and methodological clarifications. Section 4 presents the main results of our incidence analysis. Section 5 discusses the fiscal sustainability of Argentina's growing public spending. The main conclusions are summarized in section 6 .

\section{SOCIAL SPENDING IN ARGENTINA: A BIRD'S EYE VIEW}

Before we describe the social spending categories analyzed in this paper, some definitions are in order. In Argentina spending at the state and municipal levels is quantitatively important. Hence, our definition of Total Government Spending includes consolidated spending by the federal, provincial and municipal governments, and the City of Buenos Aires (Ciudad Autonoma de Buenos Aires). Primary Government Spending is equal to Total Government Spending minus debt servicing. Social Spending corresponds to the conventional definition of social spending: ${ }^{6}$ i.e., it includes cash

\footnotetext{
${ }^{3}$ Primary government spending here includes consolidated spending by federal, state and municipal governments, and the City of Buenos Aires (Ciudad Autonoma de Buenos Aires) and excludes debt servicing.

${ }^{4}$ Collected by the Instituto Nacional de Estadisticas y Censos (INDEC) of Argentina.

5 The pioneer study was Petrei (1987), followed among other studies by DGSC(1994), DGSC(1999), Gasparini (1999) and DGSC (2002).

${ }^{6}$ The main difference between Social Spending Benchmark and the government's definition of Social Spending is that the former does not include: contributory health insurance and other social assistance for formal workers (so called "Obras Sociales"); contributory health insurance and social assistance for retired formal workers (PAMI); nutrition programs; contributory family allowances; other federal, provincial and municipal social assistance spending
} 
transfers, public spending on education, health, water and sewerage, housing and an assortment of other contributory and noncontributory social programs. Contributory pensions are considered a separate category and are not classified under social spending.

The categories for which we are able to undertake the incidence analysis include the main cash transfers, noncontributory pensions, and public spending on education and primary healthcare; hereafter we shall refer to the sum of these categories as Social Spending Benchmark. Specifically, Social Spending Benchmark includes: direct cash transfers, noncontributory social assistance pensions, moratorium pensions, education, and health. In our benchmark scenario, contributory pensions are included under net market income. Since, as discussed Lustig, Pessino, and Scott (2012), contributory pensions are a mix of deferred market income and government transfers, we also carry out the benefit incidence analysis with contributory pensions included under government transfers. The category of Social Spending Benchmark plus contributory pensions is called Social Spending Sensitivity. In what follows, we present a brief description of each category included in the incidence analysis.

\subsection{Direct Cash Transfers}

Direct Cash Transfers (excluding noncontributory pensions) include the following programs. Jefes y Jefas de Hogar Desocupados (JJHD), Ingreso para el Desarrollo Humano (IDH) before 2006, Familias after 2006, scholarship programs, unemployment insurance, and Asignacion Universal por Hijo (AUH). The total amount spent on these cash transfers as a share of GDP was 1.3 percent in 2003, 0.7 percent in 2006 and 0.8 percent in $2009 .^{7}$ It is important to note that 2003 was an extraordinary year; as a fall-out of the 2001-2002 macroeconomic crisis, unemployment was equal to 17.2 percent, $^{8}$ and cash transfers to the unemployed were significantly expanded. With economic recovery and the accompanying decline in unemployment, these programs were - naturally - scaled back.

i. Jefes y Jefas de Hogar Desocupados (JJHD) (Unemployed Male and Female Heads of Household) is a workfare program launched in 2002 in response to the 2001-2002 crisis (theoretically, conditional on being unemployed, but enforcement has been rather weak). It consists of a monthly payment of $\$ 150$ (equivalent to US\$52 in 2003) until the beneficiary finds a job in the formal sector or is transferred to a new program. The target population is comprised of unemployed household heads with dependents (children aged less than eighteen or people who are incapacitated), regardless of whether the family lives in poverty. In contrast to its predecessor, the Trabajar program, JJHD does not have

(community-level spending); water and sanitation; housing and other urban services; and, culture (other spending under education).

${ }^{7}$ Budget data for the categories discussed in this paper was obtained from various official sources. In particular, the Ministry of Social Development and ANSES's websites, as well as the publications cited in this article. Regretfully, the Argentine government does not publish this information in one place and it would be very tedious (almost impossible) to describe the process followed by the authors to generate this information.

8 This is the simple average of the first and second semester unemployment rate of the twenty-eight urban conglomerates from EPH (INDEC web page). 
an explicitly stated poverty focus (Galasso and Ravallion 2004); however, JJHD is much larger so one would expect its poverty reducing impact to be quite bigger than Trabajar's.

Spending on the program was approximately equal to 1 percent of GDP in 2003 and decreased to 0.03 percent of GDP in 2009. In 2009, there were approximately 450,000 beneficiaries, according to official records.

ii. Programa Familias para la Inclusion Social (Families Program for Social Inclusion) is a conditional cash transfer (CCT) launched in 2006. The target population is household heads with less than complete secondary education and with two or more children younger than nineteen (or handicapped of any age). The target population is mostly restricted to previous beneficiaries of JJHD and IDH. ${ }^{9}$

Female household heads are the prime beneficiaries of the subsidy; in case of their absence, the father is the recipient. The heads receive a monthly payment of $\$ 155$ with one child and $\$ 30$ more for each additional child, up to a maximum of $\$ 305$ (equivalent to US\$100 in 2006) which corresponds to a household with six children younger than nineteen years of age. There is no time limit to the reception of the benefit unless, when adding the income of the rest of family, income exceeds the legal minimum wage. The subsidy is conditional on fulfilling the vaccination calendar and on all children attending or finishing secondary school. With the creation of AUH, it is expected that the Familias program will be gradually phased-out as beneficiaries are moved to the new AUH (described immediately below).

The number of beneficiaries was equal to 695,177 families in 2009, according to official records. Spending on the program was equal to 0.08 percent in 2003 (in IDH) and 0.05 percent of GDP in 2009.

iii. Asignacion Universal por Hijo (AUH) (Universal Child Allowance) is a large-scale targeted conditional cash transfer (CCT), launched in November 2009. The target population is families with children (aged eighteen or younger) whose household head is unemployed or working in the informal sector, and who do not receive another form of family allowance. If employed in the informal sector, the income should be below the minimum wage. The transfer is set at $\$ 180$ (equivalent to US\$49 in 2009) a month per child (until a maximum of five children) to every beneficiary household. Of this amount, $\$ 30$ per month per child is retained until it is demonstrated that the school and vaccination requirements are met.

According to official records, in 2010 there were 1.87 million household (3.5 million children) enrolled in the program. Spending was 7,164 million pesos in 2010 or approximately 0.6 percent of 2009 GDP.

\footnotetext{
${ }^{9}$ Since new beneficiaries were not allowed in this program initially, the conditions of eligibility apart from belonging first to JJHD or Familias was not clearly set beyond mentioning the educational requirement or the "vulnerability or poorness" of the household.
} 
iv. Scholarship Programs (Programa Nacional de Becas Estudiantiles (PNBE) para la Inclusion Social) is a set of programs originally launched in 1997 as the Programa Nacional de Becas Estudiantiles (PNBE) that expanded in 2002 in response to the 2001-2002 crisis and has since added different types of scholarships for special groups, including scholarships to bring children back to school, scholarships for children in rural schools, inclusion of children with judicial processes, and scholarships for technical training, among others. The scholarships are meant to increase school retention, primarily in secondary school among poor families; beneficiary households should earn incomes of $\$ 1,200$ (equivalent to US $\$ 327$ in 2009) or below. The scholarship consists of a yearly transfer of $\$ 900$ (US\$245 in 2009).

Spending on the PNBE program was approximately equal to 0.04 percent of GDP in 2003 and decreased to 0.02 percent of GDP in 2009. In 2009, there were approximately 500,000 beneficiaries, according to official records. ${ }^{10}$

v. Unemployment Insurance (Seguro de Desempleo) is a contributory program launched in 1993 . There is a basic unemployment benefit that is calculated as half of the best remuneration in the last six months of employment, but which cannot exceed $\$ 300$ per month (US\$82 in 2009), or be less than $\$ 150$ per month (US\$41 in 2009). The duration of the unemployment benefits is determined based on the time a person has been employed and contributing to the social security system in the three years prior to the occurrence of unemployment. Insurance for Training and Employment (Seguro de Capacitaciony Empleo) is a noncontributory program launched in 2004 for unemployed individuals that transfers $\$ 225$ per month in 2009 (US\$61 in 2009). Beneficiaries must complete their schooling or be enrolled in specialization courses or training programs.

Spending on these programs was approximately equal to 0.23 percent of GDP in 2003 and decreased to 0.08 percent of GDP in 2009. In 2009, there were approximately 147,000 beneficiaries of the contributory unemployment insurance according to official records. ${ }^{11}$

\subsection{Noncontributory Pensions}

Noncontributory pensions include a social assistance program that has existed since 1948 (which, from now onwards, we shall call social assistance pensions) and moratorium pensions, introduced in 2004 through a series of laws and decrees, one of which was still in force in $2009 .{ }^{12}$ In this paper, the sum of the two shall be called "noncontributory pensions." It should be noted to avoid confusion that in Argentina's official classification, only the first are called noncontributory pensions.

\footnotetext{
${ }^{10}$ See Rosas (2007) on the description of the scholarship programs and estimated amount of benefits and beneficiaries. The number of the total beneficiaries and budget of all the scholarship programs that increased in diversity since 2004 is not documented well and hence is not included. Therefore, these amounts are underestimating the total amount of scholarships received by students, especially in 2006 and 2009.

${ }^{11}$ See Boletin Estadistico de la Seguridad Social 2010 (ANSES). The number of beneficiaries of the Seguro de Capacitacion y Empleo could not be found in any of the many sources that were consulted.

12 This moratorium law was enacted in 1995, but in 2004-2005 it was transformed into a permanent entitlement. The number of beneficiaries will decline over time and eventually reach zero since it has a fixed date until when the moratorium is applied.
} 
However, strictly speaking, this is inaccurate. Moratorium pensions are, in practice, much closer to a noncontributory pension than to the formal sector social security contributory pension.

i. Pensiones Graciables y Asistenciales (Social Assistance Noncontributory Pension) include old-age pensions and other special benefits, some of which have been in place since 1948. The transfers are set to be equal to or below the minimum level of contributory pensions, depending on a series of criteria. In December 2009, the average monthly social assistance old-age pension was equal to $\$ 723$ (equivalent to US $\$ 195$ in 2009) and for other types of pensions the average was equal to $\$ 1,011$ (equivalent to US\$272 in 2009).

From December 2002 to 2009 the total of social assistance pension beneficiaries increased from 332,144 to $719,597 .{ }^{13}$ Spending on the program was 0.2 percent and 0.5 percent of GDP in 2003 and 2009 , respectively.

ii. Moratoria Previsional (Pension Moratorium) consists of noncontributory or partially contributory - as explained further below - pensions and was launched through the passage of two laws in 2004 and $2005 .{ }^{14}$ While the first law expired in 2007, the second continues through the present.

The target population is women aged sixty or older and men sixty-five or older who have not fulfilled the requirement necessary to receive contributory pensions after thirty years of contributions to the system. Beneficiaries must pay back part of what they should have contributed; the amount is subtracted from the pension during the first five years in which benefits are paid. An eligible individual that never contributed to the system will receive approximately $\$ 395$ per month (US\$107 in 2009) for the first five years - an amount that is equivalent to 51 percent (49 percent is the maximum deduction allowed) of the moratorium pension of approximately $\$ 770$ per month (US\$208 in 2009). After five years, he or she will start to receive the full amount of the moratorium pension.

The number of beneficiaries was negligible in 2003 (mostly surviving from previous moratorium laws in the nineties), about 200,000 in 2006 and, at the end of 2009, there were approximately 2,200,000 beneficiaries. The number of beneficiaries of the pension moratorium will decline over time and eventually reach zero since the moratorium applies only to people who were born before 1975. Spending on the moratorium program was approximately 0.4 percent of GDP in 2003 and 2.4 percent in $2009 .^{15}$

\subsection{Contributory Pensions}

The contributory pension system was launched in 1904 but suffered a series of fundamental changes in the twentieth century, and especially during the last twenty years. In particular, in 1994 the pay-as-

\footnotetext{
13 According to Boletin Estadistico de la Seguridad Social 2010 (ANSES).

14 These are the Law 25.994/04 of Previsional Inclusion and Decree 1454-05 that extended an expired Moratorium Law 24476 from 1995. While the 2004 law expired in 2007, the second is still 'alive' and applies to individuals who contributed between January 1, 1955 and September 30, 1993.

15 Since the official budget does not discriminate between moratorium and nonmoratorium pensions, the estimation is based on the number of moratorium benefits times 95 percent of the minimum pension
} 
you-go system was replaced by a mixed system with both a pay-as-you-go pillar and an individualized accounts pillar. ${ }^{16}$ The individualized accounts pillar was nationalized in December 2008 , and the assets of nearly US $\$ 30$ billion dollars that belonged to people who had invested in the individualized accounts were confiscated and transferred to the state-run social security administration. ${ }^{17}$ The current system is similar to the previous pay-as-you-go pillar, where the pension consists of a basic pension plus an additional pension based on earnings over the last ten years. The latter is not related to the amounts accumulated in the individualized accounts so, essentially, a number of people might have lost a significant portion of their savings. ${ }^{18}$ The eligibility requirements of the 'new' system did not change: people must accumulate thirty years of contributions to receive a pension and the retirement age is set at sixty for women and sixty-five for men.

The contributory pension system has had a roughly constant number of beneficiaries since 2003, in the order of 3.3 million. Spending on the contributory program was approximately 6.2 percent of GDP in 2003, 5.7 percent in 2006 and 7.2 percent in 2009. In 2003 and 2006, the pay-as-you-go component of this spending was not fully funded by the contributions to the system but had a deficit of 2.3 and 1.4 percent of GDP, respectively.

\subsection{Education}

Education is a responsibility shared by the national government, the provinces and federal district and private institutions. The public education system includes primary, secondary and tertiary schooling. In 2009 it accounted for 76 percent of elementary school enrollment, 72 percent of secondary school enrollment, and 73 percent of post-secondary enrollment (superior and university). At present, preschool (for five-year-olds), elementary school and secondary school are mandatory. Public spending on education equaled 3.4 percent in 2003, 4.3 percent in 2006 and 5.6 percent of GDP in 2009.

\subsection{Health}

Health spending analyzed here includes spending on public health services (in hospitals and other public health facilities) and spending on public health campaigns. This definition of health spending does not include Obras Sociales or PAMI spending, which is mostly funded through workers' contributions. Public spending on health was equal to 1.9 in 2003, 2.0 in 2006 and 2.6 percent of

\footnotetext{
${ }^{16}$ Under this system, the insured had a choice between the public insurance and a system of individual pension accounts, managed by private institutions known by their acronym in Spanish as AFJPs. With the macroeconomic crisis of 20012002, Argentina's government lost access to funding through the market and the AFJPs were forced to buy US $\$ 2.3$ billion low-interest government bonds on which the government defaulted in 2002.

17 The social security administration is called Administracion Nacional de la Seguridad Social/National Administration of Social Security (ANSES for its acronym in Spanish).

18 At the end of 2008, a law known as the "mobility law" was passed. It required that pensions be adjusted twice a year (in March and September), with a formula that takes into account the evolution of wages, tax collection that goes to social security, total social security revenues, and the number of beneficiaries.
} 
GDP in 2009. (The rest of public spending on health is included in Other Social Spending in table 1).

\section{DATA AND METHODOLOGICAL HIGHLIGHTS}

All the calculations presented here are made with data from the household surveys (EPH) collected by INDEC in 2003 (2nd Semester), 2006 (2nd Semester) and 2009 (1st Semester). ${ }^{19}$ The EPH reports individual characteristics, labor force participation, employment/unemployment, and labor and non-labor income of all household members by source, including several cash transfer programs from the government.

The survey covers urban areas only and is representative of 62 percent of the total population; the excluded population is mainly small urban areas and the rural sector. Although the survey does not include rural areas, we - as well as the rest of the studies that exist for Argentina - are assuming that this will not affect our conclusions in any significant way. That is, the evidence, scant as it is, does not seem to suggest that excluding the rural areas will introduce a systematic 'bias' in the results as far as the impact of cash transfers on poverty goes. ${ }^{20}$

Regarding the impact on income distribution, we really do not know if we can assume that results would remain unaffected if rural areas were included. Our view here is that with EPH we get a fairly accurate assessment of the situation of two-thirds of the population in Argentina and that if it were possible to include rural areas our results might change, but not in a systematic way. In other countries in Latin America, excluding rural areas would result in systematically lower market income poverty rates, lower coverage of social programs and higher market income inequality. We would tend to underestimate the redistributive effort of the government if rural areas were not included. ${ }^{21}$ If Argentina is assumed to be similar to the other countries, then here we are probably underestimating the redistributive impact of fiscal policy, rather than the other way around. Our results would be a lower bound. However, Argentina is mainly an urban country (90 percent of the population lives in urban areas) with a relatively small share of indigenous population and a high coverage of social programs in both urban and rural areas. ${ }^{22}$ Hence, we may not be underestimating the redistributive effect of fiscal policy after all.

We do not scale-up the income data from the survey to national accounts when estimating the redistributive impact of imputed public spending because Argentina does not report measures of

${ }^{19}$ For more details see http://www.indec.gov.ar/.

20 We base this on the following factors. Using a one-time nationally representative survey, Fiszbein, Giovagnoli, and Aduriz (2003) found that “...even though the incidence of poverty/indigence is, as expected, much higher in rural areas, the addition of rural areas in the estimation does not have a significant effect on national rates given the relative size of the two groups" (148). A qualitative study on social program coverage in rural areas by Demombynes and Verter (2007) found that about 50 percent of the households in rural areas received benefits from the existing programs in 2007.

21 See Lustig et al. (2012).

22 For how widespread the coverage of AUH and pension programs is see

http://www.anses.gob.ar/blogdeldirector/archives/2474. 
disposable income in its national accounts. ${ }^{23}$ However, we did check if scaling-up using total private consumption (instead of disposable income which does not exist) as a control total would affect the results from 2009. We found that the final income Gini with scaling-up was equal to 0.371 instead of 0.366, a small difference especially when compared to the decline from disposable income Gini to final income Gini found here.

The allocation and amount of several of the direct cash transfers is directly identified based on the information reported by households in response to specific questions. This is the case of JJHD, unemployment benefits, and scholarships. Transfers received from IDH and Familias, however, are inferred from a question that asks if the household receives any additional cash transfer program.

In the case of AUH, since it did not exist until November 2009, the benefits have to be simulated. We follow the methodology described in Pessino (2010) that simulates most of the conditions necessary to assess the program, such as the requirement that none of the parents of the children work in the formal sector or receive pensions, except for work in the domestic service, and that informal workers earn less than the minimum wage (basically none of them should be receiving family allowances). But we could not impose conditions dealing with migration and time of residence. We also assume that if families are accepted into $\mathrm{AUH}$, they are automatically dropped from Familias and other programs, as the law requires. Agis, Cañete, and Panigo (2010), however, allows for an "inclusive" option, in which families violate the law and have more than one social program per family, concluding that poverty would then decrease even more. In other words, if the law is violated in practice frequently, then our estimate should be viewed as a lower bound (conservative) on the simulated benefits of AUH because we do not permit a household receiving benefits from another cash transfer program to be eligible for AUH. The number of beneficiaries obtained from this simulation country-wide is approximately 1.8 million families. This number coincides with the number of head of households reported by ANSES as receiving the AUH transfers. $^{24}$

Benefits from noncontributory pensions (which include moratorium and social assistance pensions) could not be independently identified in the surveys; they are lumped together with contributory

\footnotetext{
${ }^{23}$ Not scaling-up has the problem that the redistributive impact of spending categories that are imputed by dividing the reported public spending (from public accounts) by total beneficiaries (from public accounts) could be "exaggerated" whenever the incomes in the survey are (substantially) lower than those in public accounts. For example, let's say that total household disposable income in the survey is 60 percent of what national accounts report for a (relatively) comparable category of disposable income but disposable income in the survey is not scaled-up. The income in-kind from, let's say, primary education is scaled-up by definition because it is calculated by dividing public spending on primary education by the number of children enrolled in primary education and this amount is allocated to each household depending on how many of its children are enrolled in primary education. When we do this, the incidence and redistributive impact of public spending on primary education (as well as any other imputed public expenditure) is likely to be blown out of proportion. However, our sensitivity analysis for 2009 suggests that the effect on the final income Gini would be very small.

${ }^{24}$ The number of beneficiaries reported by ANSES were around 1.9 million since November 2009 (1.871 million in November 2009 and 1.897 million in March 2012). From Boletin Estadistico de la Seguridad Social, Ministerio de Trabajo, Empleo y Seguridad Social, Secretaria de Seguridad Social, Cuarto Trimestre 2011, 1er Trimestre 2012.
} 
pensions and therefore must be inferred. Since all the "new" pensioners of the noncontributory pension (i.e., those that were added since the passage of the pension moratorium decrees in 2004) get the minimum pension (of the contributory system) minus the payments required to qualify for the pension, to identify the beneficiaries of the pension moratorium and social assistance pensions together we find the individuals reporting a pension below the minimum contributory pension in each of the years of the survey. ${ }^{25}$ Hence, reported pensions that are below the minimum contributory pension are subtracted from reported income to obtain net market income, the initial income category for our analysis since we do not analyze the tax side of the fiscal system. It should be noted that this entails a risk because due to the impossibility of distinguishing between the contributory and noncontributory pensions, we may inadvertently also be netting out contributory pensions whose level might be below the minimum, such as the survivor's pension. Hence, we may be possibly overestimating the number of the net market income poor among the people. However, in terms of the marginal incidence effect of moratorium pensions this problem may be a moot point because the beneficiaries of survivor pensions is not likely to have increased between 2003 and 2009, so attributing the change to the expansion of beneficiaries of noncontributory pensions due to mainly the moratorium pensions seems a plausible assumption.

The in-kind transfers in education and health were imputed. The surveys include questions about school attendance by education level, and type of health care coverage. To impute the benefits of education spending, we divide the budget per school level, primary (starting in preschool), secondary, and university and tertiary level, by the number of enrolled students in each level in public school. We exclude other items included in the education budget that are not explicitly aimed at these levels, and hence we did not deduct administrative costs. ${ }^{26}$

The surveys do not include questions on the use of public health facilities, only if an individual is or is not affiliated with a health provider, so individuals that declare having no health insurance (either private or from Obras Sociales) receive the imputed benefit. In this case, the in-kind transfer was obtained from the per capita government expenditure on health from World Health Statistics 2009 (WHO). ${ }^{27}$

\footnotetext{
${ }^{25}$ Monthly minimum contributory pensions were considered to equal $\$ 220$ in 2003, \$470 in 2006 and $\$ 770$ in 2009 .

${ }^{26}$ Budget figures are obtained from the Secretaria de Politica Economica from the Ministry of the Economy http://www.mecon.gov.ar/ and enrollment figures were obtained for primary (including preschool), secondary and tertiary (nonuniversity) school from the Anuario Estadístico Educativo (Several Years) from 2003-2009 from the Direccion Nacional de Informacion y Evaluacion de la Calidad Educativa- Ministerio de Educación, Ciencia y Tecnología de la Nación. Diniece http:// diniece.me.gov.ar and for university enrollment from Anuario de Estadisticas Universitarias (Several Years), from the Secretaria de Politicas Universitarias, Ministerio de Educación, Ciencia y Tecnología de la Nación. The estimated benefits were: in $2003, \$ 1,255, \$ 1,701$ and $\$ 1,907$ per year for primary, secondary and tertiary (university and nonuniversity) level, respectively; in $2006, \$ 2,559, \$ 4,225$ and $\$ 3,872$ per year for primary, secondary and tertiary university level, respectively; and, in $2009 \$ 5,484, \$ 8,527$ and $\$ 8,443$ per year for primary, secondary and tertiary level, respectively.

${ }^{27}$ Per capita government expenditure on health (PPP int.\$) can be obtained from World Health Statistics for several years. For 2009 see, http://www.who.int/whosis/whostat/EN_WHS2011_Full.pdf and for earlier years http://apps.who.int/ghodata/?vid=1901. It was multiplied by PPP each year, to obtain an estimated in-kind transfer of $\$ 422$ for 2003, $\$ 789$ for 2006 and $\$ 1,365$ for 2009 . This cost was similar to the cost of one of the least expensive health insurance programs provided in the Province of Buenos Aires by Instituto de Obra Médico Asistencial (IOMA), (the
} 


\section{SOCIAL SPENDING AND INCOME REDISTRIBUTION IN ARGENTINA: MAIN RESULTS}

\subsection{Evolution of Net Market and Disposable Income Inequality and Poverty}

Between 2003 and 2009, both the net market income and the disposable income Gini coefficients and headcount ratios fell quite dramatically (table 2). This is true for any of the considered poverty lines, and for both the benchmark and sensitivity analysis. ${ }^{28}$ When we compare our results with those of other sources, we find similar levels and exactly the same trends. For example, SEDLAC's disposable income Gini coefficients and headcount ratios for the US\$2.50 PPP and US $\$ 4$ PPP per day poverty lines differ very slightly from the ones calculated here (SEDLAC 2012). ${ }^{29}$ The only year for which the comparison of levels is not possible is 2009 because we included the simulated AUH transfer in our calculations of inequality and poverty. Since in 2009 AUH did not exist, SEDLAC's numbers could not have included this transfer. As expected, our poverty rates are smaller than SEDLAC's for 2009; our disposable income Gini is lower too, which is consistent with the fact that AUH is progressive in absolute terms (more on this below).

It is important to note that 2003 was a year in which inequality and poverty reached historic peaks in the aftermath of the macroeconomic crisis in $2001-2002 .^{30}$ This is not the place to discuss the factors behind the secular and transitory causes of inequality and poverty trends in Argentina. The interested reader should consult, for example, Gasparini and Cruces (2010). However, one should be aware that here we are analyzing changes in social policy during an unusual period. The severe macroeconomic crisis was followed by an unprecedented commodity-led boom. After peaking in 2003 , inequality and poverty fell rapidly. However, the remarkable decline in inequality and poverty since 2003 is, essentially, a reversal to what prevailed in the early 1990s. In 2009, the Gini coefficient reached a level similar to that of 1992 and the headcount ratio for "extreme poverty" (poverty line equal to US $\$ 2.50$ per day) was still slightly above the one prevailing in 1992 (see SEDLAC 2012). Nevertheless, witnessing a decline in inequality and poverty is certainly good news.

public health provider of the Province of Buenos Aires) of a little more than 1,200 pesos per capita per year in 2009. On the high end, private insurance companies least expensive plans charged $\$ 2,100$ per year. This shows that the cost estimated by WHO seems to be somewhere in between the costs of various providers that could offer health insurance to the poor in 2009, so we deemed it appropriate and adopted it for this study.

28 The results for the sensitivity analysis are in the unpublished appendix available upon request. Note that in the sensitivity analysis, the only indicators that change are those calculated with net market income. Since under the benchmark scenario (sensitivity analysis) contributory pensions are included under net market income (government transfers), net market income poverty is always lower (higher) under the benchmark (sensitivity), almost by definition. ${ }^{29}$ The comparison is in the unpublished appendix available upon request.

30 Argentina has had many recurrent crises in every decade in the last fifty years, such as in 1989 and in 2002, with inequality and poverty increasing in each crisis, following with a decline if the crisis was successfully left behind. Poverty and inequality increased again, mainly due to rising unemployment and the Tequila and Russian crisis in the second half of the nineties, culminating in the worst increase ever after the default and devaluation of 2001-2002. 
In terms of redistributive effectiveness, one can see in table 2 that the government has been able to generate more poverty reduction per amount spent over time but the effectiveness to reduce inequality has declined. This in fact reflects the increase in the budget share of noncontributory pensions and a decrease in the share of programs targeted relatively more to the poor such as JJHD, Familias and AUH.

\subsection{Social Policy vs. Market Forces}

Again, this is not the place to present a thorough analysis of the underlying determinants of the evolution of inequality and poverty in Argentina. We can, however, assess the extent to which the observed declines in the disposable income Gini coefficients and headcount ratios were due, primarily, to a reduction in net market income inequality and poverty and to the increase in the size and progressivity of social spending.

Table 3 provides information about the extent to which the transfer system has mitigated market income inequality and poverty, and how such effects have evolved over time. To calculate the contribution of the "redistribution component," we simply subtract the change in the net market income Gini (headcount ratio) between any pair of years from the change in the disposable income Gini (headcount ratio) between the same end points.

Put in formulas, let $G_{m}^{t}$ and $G_{d}^{t}$ be the market and disposable income Ginis in year $t$, respectively; and, $G_{m}^{\mathrm{t}^{\prime}}$. and $G_{d}^{\mathrm{t}^{\prime}}$ be the market and disposable income Ginis in year $t^{\prime}$. Let's define $R^{t}$ and $R^{\mathrm{t}^{\prime}}$ as the portion attributable to redistribution of the change from market income Gini to disposable income Gini. We can then write:

$G_{d}^{t}=G_{m}^{t}-R^{t}$

and

$G_{d}^{\mathrm{t}^{\prime}}=G_{m}^{\mathrm{t}^{\prime}}-R^{\mathrm{t}^{\prime}}$

Subtracting (2) from (1) yields:

$\mid\left(G_{d}^{\mathrm{t}^{\prime}}-G_{d}^{t}\right)=\left(G_{m}^{\mathrm{t}^{\prime}}-G_{m}^{t}\right)-\left(R^{\mathrm{t}^{\prime}}-R^{t}\right)$

or,

$\mid\left(R^{\mathrm{t}^{\prime}}-R^{t}\right)=\left(G_{m}^{\mathrm{t}^{\prime}}-G_{m}^{t}\right)-\left(G_{d}^{\mathrm{t}^{\prime}}-G_{d}^{t}\right)$

So, $\left(R^{\mathrm{t}^{\prime}}-R^{t}\right)$ is the portion of the change in the disposable income Gini between two points in time that can be attributed to a change in the redistribution component (in comparison to the change in the market income Gini). A similar formula can be calculated for the headcount ratio or any other inequality and poverty indicator. 
We find that, for the Gini coefficient, the change in the redistribution component accounts for 12 percent of the change in the disposable income Gini between 2003 and 2009. ${ }^{31}$ If we take the two subperiods separately, however, there are two distinct patterns. Between 2003 and 2006, the change in the disposable income Gini is fully due to the decline in the net market income Gini. In fact, the latter more than compensated for the reduced role of redistribution: in other words, in an accounting sense, if the net market income Gini in 2006 had been the same as in 2003, the disposable income Gini in 2006 would have been higher than in 2003. In contrast, between 2006 and 2009, over 40 percent of the decline in the disposable income Gini is accounted for by the redistribution component. This is in large part due to the sharp increase in beneficiaries of the pension moratorium. The story for poverty is similar but even more forceful: close to 90 percent of the decline in poverty between 2006 and 2009 is due to redistributive policies. The pension moratorium seems to have had a more powerful poverty-reducing than an inequality-reducing effect.

Care must be taken in interpreting such a comparison, because market incomes react to transfers. That is, the figures do not necessarily represent what inequality and poverty rates (in terms of net market income) would be in the absence of transfers. However, since we have information on the pre- and post-transfers inequality and poverty levels before and after the implementation or expansion of several of the major transfer programs, we can assume - with caution - that the observed net market income before and after the programs were introduced is reflecting - among other things - behavioral responses to the programs. That is, because we are focusing on the marginal incidence effects, the behavioral responses should be reflected in measured net market income in 2006 and, more forcefully, in 2009.

\subsection{The 'Explosion' of Noncontributory Pensions}

The large contribution of transfers to the reduction of disposable income inequality and poverty between 2006 and 2009 was primarily due to the sharp expansion of noncontributory pensions; in particular, to the launching of the pension moratorium. Noncontributory pensions are progressive in absolute terms (table 4) and, as a share of GDP, they rose from 0.7 percent in 2003 to 2.9 percent in 2009 (table 1). While the degree of progressivity rose slightly (table 4), the inequality and poverty reducing effect of noncontributory pensions is primarily due to their large expansion. Figure 1 shows the evolution of the three types of pensions: social assistance, moratorium, and contributory pensions. The increase in beneficiaries from 3.6 million to 6.3 million observed between 2003 and 2009 is explained almost entirely by the increase in beneficiaries in noncontributory pensions. The proportion of beneficiaries with noncontributory social assistance and moratorium pensions increased from 9.3 percent to 47.8 percent of the total population receiving pensions.

[table 4] [figure1] 
By comparing the covered and uncovered population age sixty-five and over between 2003 and 2009 (figure 2), we find that the coverage rate increased from 69.6 percent to 88.6 percent, and the largest increase was among women, whose coverage increased from 65.8 percent to 91.3 percent. In fact, in terms of coverage, by 2009 women surpassed men by over 6 percentage points.

Contributory pensions remained at close to 7 percent of GDP throughout the decade. The total pension system in Argentina in 2009 benefited 6.3 million people at a cost of 10 percentage points of GDP. In the benchmark scenario, contributory pensions are included under 'market income.' In the sensitivity analysis, they are included under government transfers.

It is important to note that, since 2003, there has been an implicit redistribution from pensioners in the formal contributory sector to those in the noncontributory sector (or to other sectors receiving government transfers and subsidies). In formal terms, the moratorium pensions are paid out of the same pool of revenue as that collected from the contributory system. In addition, the pensions above the minimum have not been adjusted for inflation at the same rate as the minimum pensions since 2002, in spite of this being part of the legal charter of the social security laws. This has led to a significant erosion of their purchasing power and has resulted in a myriad of lawsuits against the government: ${ }^{32}$ between December 2002 and December 2009, minimum pensions in real terms increased by 70 percent while average ones rose by only 19 percent leading to a narrowing of the minimum/average pension from 54 percent to 78 percent during the same period. Although people who receive a pension higher than the minimum pension are not poor, they are definitely not rich. Many are what we tend to call the lower-middle class. In addition, this breach of commitment will create disincentives to contribute to the formal system whenever this can be avoided or eluded. ${ }^{33}$ Another form of redistribution has occurred from the individuals who had their contributions saved in the individualized accounts that were confiscated in 2008 because when they retire their pension will be determined by the rules that apply to the pay-as-you-go system, regardless of how large the size of their account was at the time of confiscation.

\subsection{The AUH and Other CCTs}

All cash transfers programs analyzed here are progressive in absolute terms (table 4). In spite of the launching of AUH at the end of 2009, the overall share of cash transfers - as a proportion of GDP - was lower in 2009 than in 2003 (table 1). This happened because with the economic recovery and subsequent boom the emergency employment program was scaled back significantly. However, since GDP was higher in 2009, the cash transfers' budget in per capita terms was also higher. This, together with the fact that - as shown in table 4 - the progressivity of the individual programs

${ }^{32}$ On the proliferation of lawsuits see http://www.lanacion.com.ar/1318287-jubilados-se-triplican-los-fallos

${ }^{33}$ For preliminary estimates on the effect on employment from the pension moratorium, see Bosch and Guajardo (2012). 
tended to rise (or be high to begin with such as the case of AUH), means that the contribution of direct cash transfers to inequality and poverty reduction rose.

With the expansion of noncontributory pensions and the launching of AUH, the coverage among the poor of all cash transfers combined rose by a whopping 30 percentage points for extreme and moderate poor between 2003 and 2009 (figure 3). In 2009, more than 90 percent of the extreme poor and more than 80 percent of the moderate poor are covered by at least one of the CCTs or noncontributory pensions.

\subsection{Education and Health}

Public spending on education and primary healthcare are progressive in absolute terms (table 4). Spending as a share of GDP (table 1) and progressivity (table 4) increased for both over the period under analysis. If education is disaggregated by level, all but tertiary (and other education) are progressive in absolute terms; tertiary is progressive in relative terms. The degree of progressivity increased for all levels of schooling between 2003 and 2009, reflecting an increase in coverage among the poor. These auspicious results, however, have their downside. As in other Latin American countries, the better-off in Argentina have left the public school system because of its low quality. Argentina in particular is one of the worst performers in the international assessments of quality of education such as PISA and SERCE. It also shows one of the largest gaps in quality between private and public education.

\subsection{Nonsocial Spending: Indirect Subsidies}

Government spending on indirect subsidies equaled 5.6 percent of GDP in 2009, over 50 percent more than what is spent on cash transfers (CCTs and noncontributory pensions) (table 1). Between 2003 and 2009, the proportion spent on indirect subsidies more than doubled. These subsidies are primarily subsidies to agricultural producers, airlines, manufacturing, and transportation and energy. The latter two account for the largest share of the increase in indirect subsidies/GDP during the period. After the massive devaluation of the peso in 2001, the government did not increase the price of energy so that prices of final goods would not rise by as much. Although we do not do an incidence analysis of indirect subsidies ourselves (in large part because EPH does not have data on consumption), other sources have estimated concentration coefficients for these categories, which we have included here.

Table 4 shows the concentration coefficients for several categories of indirect subsidies. Transportation and energy subsidies are progressive only in relative terms. Agricultural, manufacturing and, very much so, airline subsidies are outright regressive (unequalizing). The budget for these three subsidies in 2009 was equal to 1.3 percent. To put this figure into perspective, the budget for CCTs was equal to 0.8 percent. Clearly, there could be an equalizing reallocation away from the regressive subsidies towards, for example, increasing the access of the poor to early- 
childhood interventions and post-secondary education, improving basic education and primary healthcare's quality, or expanding infrastructure in poor regions and neighborhoods.

\section{FISCAL SUSTAINABILITY}

While a full-blown fiscal sustainability analysis is beyond the scope of this paper, given the extraordinary expansion of primary spending in Argentina in such a short period of time, the question of how this expansion was financed is of great relevance. If we only include government revenues that are conventionally included as "above-the-line" items (following the recommendations of the IMF Government Financial Statistics Manual of $2001^{34}$ ), the fiscal surpluses (excluding debt servicing) were equal to 3.1 percent and 3.3 percent of GDP in 2003 and 2006, respectively. By 2009 , this surplus turned into a deficit equal to 1.5 percent of GDP as shown in the lower panel of table 1. Because in the official statistics the government revenues include items that should not be treated as above-the-line sources of fiscal revenues (more on this below), the official reported surpluses are larger: 3.3 percent in 2003, 3.8 percent in 2006 and 0.4 percent in 2009. Including debt servicing, the Public Sector Borrowing Requirements (PSBR), excluding unorthodox, below-the-line sources of revenue, was equal to -0.7 percent in 2003, -1.1 percent in 2006 and 4.1 percent in 2009 (recall that if preceded by a negative sign it means a surplus). Including the unorthodox sources of revenue, PSBR for 2009 was equal to 2.2 percent. $^{35} 36$

Since Argentina defaulted on its international creditors during the crisis of 2001-2002, it does not have access to external sources of funding. Thus, the government needs to finance its spending through "normal" taxes and borrowing from public enterprises and, if this is not enough, it must resort to unorthodox alternatives (which in Argentine parlance are called "creative financing") such as the inflation tax. "Normal" tax revenues rose from 23.4 percent of GDP in 2003 to 31.4 percent of GDP in 2009. There were three main sources. First, a distortionary tax on financial transactions implemented during the crisis of 2001-2002 but which has become permanent and went from zero in 2000 to 1.8 percent of GDP in $2009 .^{37}$ Second, an increase on the tax rate on primary exports, which together with the rise in commodity prices led to an increase in revenues from this tax from

\footnotetext{
${ }^{34}$ See http://www.imf.org/external/pubs/ft/gfs/manual/.

${ }^{35}$ Authors' calculations based on data from Oficina Nacional de Presupuesto y Susbsecretaria de Ingresos Publicos de la Secretaria de Hacienda y la Secretaria de Politica Economica, Ministerio de Economia y Obras y Servicios Publicos and Castineira (2010). See the latter for some details on the "creative" portion of financing federal government spending. This author and most analysts only report the federal government deficit. In this study we are estimating the national (federal, provincial and municipal) consolidated deficit.

${ }^{36} \mathrm{It}$ is important to note that the rise in the fiscal deficit is not just a consequence of counter-cyclical fiscal policies during the Great Recession in 2009. The deficit continued on its upward trend after 2009 and the Argentine government had to resort to additional sources of "creative financing." For example, in December 2009, the government created - by decree - a US\$6.6 million fund with so-called excess reserves of the Central Bank provoking the resignation of its chairman who opposed such a measure with a vengeance. This measure was blocked in the judicial system. The executive, however, pursued its goal by creating another fund - the so-called "un-indebting fund" - by which the Central Bank was obligated to transfer US\$4.2 million to the Argentine Treasury. This fund was utilized to finance the deficit in 2010 and 2011. See Argañaraz and Brugiafreddo (2012).

${ }^{37}$ See Fenochietto, Pessino and Crivelli (2012) for the impact of the Bank Transactions Tax on Deposits in Argentina.
} 
.01 percent of GDP in 2000 , to 2.5 percent in 2003 to 2.8 percent in 2009 . And, third, after 2008, the employee contributions to the nationalized social security system, which increased from 4.5 percent of GDP in 2007 to 6.7 percent in 2009, an increase of 2.2 percent of GDP. Overall, during the period from 2000 to 2009, taxes increased by 9.9 percentage points of GDP, and 80 percent of this increase is accounted for by the three forms of taxations that can have significant distortionary effects: the financial transactions tax (18 percent), export taxes (28 percent) and Social Security taxes (34 percent). ${ }^{38}$ (Of these three sources, the first one should be scrapped at the earliest, the second one is quite sensitive to the fate of commodity prices in the international market (a volatile and unreliable source) and the third should be lowered).

By 2009, however, tax revenues were not sufficient to cover the much higher levels of public spending, so the government had to resort to more unorthodox sources. These include: (1) the interests earned on the fund that was created with the assets that used to be in the individualized social security accounts (34 percent), a fund that was confiscated by the federal government in 2008 when the nationalization of the individualized accounts pillar of the social security system occurred; (2) the profits accrued to the Central Bank (22 percent) - that is, what many authors refer to as the inflation tax and, (3) special drawing rights from the IMF (44 percent) (which strictly speaking should be treated as a zero interest loan and not a revenue). However, after 2009 (3) was no longer available, and this led the federal government to tap international reserves and profits from the Central Bank. One should note that the inflation tax is much higher than the official inflation statistics would lead one to believe; the latter have been around a third of those produced by independent, nonpartisan research institutions (who have to face fines and lawsuits for publishing inflation data different from the official data). ${ }^{39}$ Because of its lack of transparency with inflation and other statistics, Argentina is facing the prospect of being the first country to be censured by the IMF.

\section{CONCLUSIONS}

During the period from 2003 to 2009, the federal government of Argentina increased primary spending by 13.5 percentage points. Social spending expanded considerably more than nonsocial spending and the rise of primary spending was concentrated in the 2006 to 2009 period (table 1). The redistribution and effectiveness indicators look impressive: Argentina is able to lower inequality and poverty proportionately more than other countries included in this special issue and to do so with greater effectiveness (in terms of how much redistribution is obtained by peso spent). In 2009, for example, cash transfers lowered the Gini coefficient by 4.2 percentage points and the incidence of extreme poverty by almost 60 percent (table 2). Redistributive policies were particularly

\footnotetext{
38 Authors' calculations based on data from Oficina Nacional de Presupuesto y Susbsecretaria de Ingresos Publicos de la Secretaria de Hacienda y la Secretaria de Politica Economica, Ministerio de Economia y Obras y Servicios Publicos and Castineira (2010).

${ }^{39}$ On the extreme regressivity of the inflation tax during the eighties (it did not exist during the nineties and this is sometimes neglected in distributional analysis of that decade) see Canavese, Sosa Escudero, and Alvaredo, (1999).
} 
prominent in the period from 2006 to 2009 (table 3). This is mainly due to the launching of the large (quasi) noncontributory pension program - the pension moratorium - which increased the number of old-age pensioners from 4 to 6.3 million between 2006 and 2009 (with the largest increase taking place among women).

This rosy picture of Argentine redistribution policies becomes significantly tainted when one takes note of two things. The redistribution linked to the pension moratorium has been partially funded by retirees receiving above the minimum pension who are themselves part of the lower- and midmiddle class. The inequality and poverty indicators do not capture these losses because the losses inflicted on the losers are more than compensated for by the rising incomes of the poor. More worrisome, the sharp rise in public spending during the 2000s has been increasingly financed by distortionary taxes and unorthodox revenue-raising mechanisms, such as the inflation tax and the tapping of international reserves and IMF special drawing rights. In addition, one of the taxes - the export tax - is highly sensitive to commodity prices. All in all, this points to the fact that the Argentine government has embarked in a redistribution process that - to some extent - generates unfair losses (to the formal sector retirees) and may not be fiscally sustainable unless subsidies accruing to the nonsocial sectors are significantly curbed. 


\section{REFERENCES}

Agis, Emmanuel, Carlos Cañete, and Demian Panigo. 2010. El impacto de la asignación universal por hijo en Argentina. CEIL-PIETTE Working Paper, Buenos Aires: Argentina. ANSES. 2010. Boletín Estadístico de la Seguridad Social: Segundo Semestre 2010. Buenos Aires, Argentina: Dirección Nacional de Programación Económica y Normativa, Ministerio de Trabajo, Empleo y Seguridad Social.

ANSES. 2012. Nueva Metodología 2012. Boletín Estadístico de la Seguridad Social: Cuarto Trimestre 2011 - Primer Trimestre 2012. Buenos Aires, Argentina: Dirección Nacional de Programación Económica, Ministerio de Trabajo, Empleo y Seguridad Social.

ANSES. 2012. ANSES acerca la Seguridad Social a las comunidades indígenas.

http://www.anses.gob.ar/blogdeldirector/archives/2474

Argañaraz, Nadin, and María Pía Brugiafreddo. 2012. Balance fiscal definitivo 2011. Escenarios fiscales alternativos para el 2012. Instituto Argentino de Análisis Fiscal (IARAF) Economic Report 147, Córdoba, Argentina.

Bosch, Mariano, and Jarret Guajardo. 2012. Labor Market Impacts of Non-Contributory Pensions: The Case of Argentina's Moratorium. IADB and Save the Children, Washington, D.C.

Canavese, Alfredo, Walter Sosa Escudero, and Facundo Alvaredo. 1999. El Impacto de la inflación sobre la distribución del ingreso: el impuesto inflacionario en la Argentina en la década del ochenta. In La Distribución del Ingreso en la Argentina, 265-289. Buenos Aires, Argentina: FIEL.

Castiñeira, Ramiro. 2010. La Situación Fiscal y el Pago de la Deuda con o sin Fondo del Desendeudamiento. Argentina Macroeconomic Outlook, Econometrica S.A., Buenos Aires: Argentina.Demombynes, Gabriel, and Dorte Verter. 2007. Los pobres invisibles. Un panorama de la pobreza rural en Argentina. World Bank report, Buenos Aires, Argentina.DGSC (Dirección de Gastos Sociales Consolidados). 1994. El Gasto Público Social y su Impacto Redistributivo. Buenos Aires, Argentina: Ministerio de Economía y Obras y Servicios Públicos.

DGSC (Dirección de Gastos Sociales Consolidados). 1999. El impacto redistributivo del Gasto Público en los Sectores Sociales. Resultados Provisorios. Ministerio de Economía y Obras y Servicios Públicos Working Paper, Buenos Aires, Argentina.

DGSC (Dirección de Gastos Sociales Consolidados). 2002. El Impacto Distributivo de la Política Social en la Argentina. Análisis basado en la Encuesta Nacional de Gastos de los Hogares. 
Ministerio de Economía y Obras y Servicios Públicos Working Paper, Buenos Aires, Argentina.

Fenochietto, Ricardo, Carola Pessino, and Ernesto Crivelli. 2012. Impact of the Bank Transactions on Deposits in Argentina. In Taxation of the Financial Sector, forthcoming, Cambridge, MA: MIT Press.

Fiszbein, Ariel, Paula Giovagnoli, and Isidro Adúriz. 2003. El impacto de la crisis argentina en el bienestar de los hogares. CEPAL Revista, Santiago, Chile.

Gasparini, Leonardo, 1999. Incidencia distributiva del gasto público social y de la política tributaria en la Argentina. In La Distribución del Ingreso en la Argentina, 347-370. Buenos Aires, Argentina: FIEL.

Galasso, Emanuela, and Martin Ravallion. 2004. Social Protection in a Crisis: Argentina's Plan Jefes y Jefas. The World Bank Economic Review 18 (3): 367-399.

Gasparini, Leonardo, and Guillermo Cruces. 2010. Las asignaciones universales por hijo en Argentina: Impacto, discusión, y alternativas. Económica 56 (1): 105-146.

Lustig, Nora, Maynor Cabrera, George Gray-Molina, Sean Higgins, Miguel Jaramillo, Wilson Jiménez, Hilcías Morán, Veronica Paz, Claudiney Pereira, John Scott, and Ernesto Yañez. 2012. Fiscal Policy, Urban-Rural Inequality and Rural Poverty in Bolivia, Brazil, Guatemala, Mexico, and Peru. International Fund for Agricultural Development (IFAD) background paper.

Lustig, Nora, and Carola Pessino. 2012. Social Spending and Income Redistribution in Argentina During the 2000s: the Rising Role of Noncontributory Pensions. Tulane University Mimeo, New Orleans, LA.

Lustig, Nora, Carola Pessino, and John Scott. 2012. Introduction. Tulane University Mimeo, New Orleans, LA.

Pessino, Carola. 2010. Commitment to Equity: An Assessment of Fiscal Policies in Argentina. IAD Report, Washington, D.C. and CIPR Report, New Orleans, LA.

Petrei, Humberto. 1987. El gasto público social y sus efectos distributivos. Un examen comparativo 3

Rosas, Maria Ester. 2007. Trabajo infantil y Programas de Transferencias en Efectivo Condicionadas en Argentina, Ministerio de Trabajo y Seguridad Social Argentina. 
SEDLAC (CEDLAS and The World Bank). 2012. http://sedlac.econo.unlp.edu.ar/eng/statistics.php, accessed October 7, 2012. 
Table 1. Government Spending by Category (as a percent of GDP): 2003, 2006, and 2009

\begin{tabular}{|c|c|c|c|c|c|}
\hline & 2003 & 2006 & 2009 & $\begin{array}{l}\text { Change 2009- } \\
2003 \text { (\% pts) }\end{array}$ & $\begin{array}{l}\text { Share of the } \\
\text { increase (in \%) }\end{array}$ \\
\hline Gross Nat Inc/capita (PPP US\$) & 8,180 & 11,740 & 14,230 & & \\
\hline Total Government Spending a & $29.5 \%$ & $32.9 \%$ & $43.2 \%$ & $13.7 \%$ & -- \\
\hline Primary Government Spending b & $27.1 \%$ & $30.7 \%$ & $40.6 \%$ & $13.5 \%$ & $100.0 \%$ \\
\hline Social Spending ${ }^{\mathrm{c}}$ & $13.0 \%$ & $15.4 \%$ & $20.6 \%$ & $7.6 \%$ & $56.1 \%$ \\
\hline $\begin{array}{l}\text { Social Spending (In Incidence } \\
\text { Analysis Benchmark) d }\end{array}$ & $7.3 \%$ & $8.3 \%$ & $11.8 \%$ & $4.5 \%$ & $33.4 \%$ \\
\hline Total Cash Transfers & $2.0 \%$ & $2.0 \%$ & $3.7 \%$ & $1.7 \%$ & $12.6 \%$ \\
\hline Cash Transfers (excluding all Pensions) & $1.3 \%$ & $0.7 \%$ & $0.8 \%$ & $-0.5 \%$ & $-4.0 \%$ \\
\hline Non-Contributory Pensions & $0.7 \%$ & $1.2 \%$ & $2.9 \%$ & $2.2 \%$ & $16.6 \%$ \\
\hline Moratorium Pensions & $0.4 \%$ & $0.8 \%$ & $2.4 \%$ & $2.0 \%$ & $14.4 \%$ \\
\hline Total In Kind Transfers & $5.3 \%$ & $6.3 \%$ & $8.1 \%$ & $2.8 \%$ & $20.8 \%$ \\
\hline Education & $3.4 \%$ & $4.3 \%$ & $5.6 \%$ & $2.1 \%$ & $15.6 \%$ \\
\hline Health Primary Case & $1.9 \%$ & $2.0 \%$ & $2.6 \%$ & $0.7 \%$ & $5.2 \%$ \\
\hline $\begin{array}{l}\text { Other Social Spending (Not in } \\
\text { Incidence Analysis) }{ }^{\mathrm{e}}\end{array}$ & $5.7 \%$ & $7.1 \%$ & $8.8 \%$ & $3.1 \%$ & $22.7 \%$ \\
\hline Non-Social Spending ${ }^{f}$ & $7.9 \%$ & $9.6 \%$ & $12.8 \%$ & $4.9 \%$ & $36.5 \%$ \\
\hline Indirect Subsidies & $2.5 \%$ & $3.8 \%$ & $5.6 \%$ & $3.1 \%$ & $23.3 \%$ \\
\hline Other Non Social Spending g & $5.4 \%$ & $5.9 \%$ & $7.2 \%$ & $1.8 \%$ & $13.2 \%$ \\
\hline $\begin{array}{l}\text { Contributory Pensions (In Sensitivity } \\
\text { Analysis) }\end{array}$ & $6.2 \%$ & $5.7 \%$ & $7.2 \%$ & $1.0 \%$ & $7.4 \%$ \\
\hline Debt Servicing & $2.4 \%$ & $2.2 \%$ & $2.6 \%$ & $0.2 \%$ & $1.3 \%$ \\
\hline \multicolumn{6}{|l|}{ Memo item: } \\
\hline TOTAL Pensions & $6.8 \%$ & $6.9 \%$ & $10.0 \%$ & $3.2 \%$ & $23.9 \%$ \\
\hline Contributory & $6.2 \%$ & $5.7 \%$ & $7.2 \%$ & $1.0 \%$ & $7.4 \%$ \\
\hline Non-Contributory & $0.7 \%$ & $1.2 \%$ & $2.9 \%$ & $2.2 \%$ & $16.6 \%$ \\
\hline $\begin{array}{l}\text { Financing of Total Government } \\
\text { Spending }\end{array}$ & $29.5 \%$ & $32.9 \%$ & $43.2 \%$ & $13.7 \%$ & $100.0 \%$ \\
\hline $\begin{array}{l}\text { Total Government “Actual" and } \\
\text { "Creative" Revenues }\end{array}$ & $30.4 \%$ & $34.5 \%$ & $41.0 \%$ & $10.6 \%$ & $77.3 \%$ \\
\hline Total Government Tax Collection & $23.4 \%$ & $27.4 \%$ & $31.4 \%$ & $8.0 \%$ & $58.3 \%$ \\
\hline $\begin{array}{l}\text { Total Government "Actual" } \\
\text { Non Tax Revenue }\end{array}$ & $6.8 \%$ & $6.6 \%$ & $7.6 \%$ & $0.8 \%$ & $6.1 \%$ \\
\hline $\begin{array}{l}\text { Total Government "Creative" } \\
\text { Non Tax Revenue }\end{array}$ & $0.2 \%$ & $0.5 \%$ & $2.0 \%$ & $1.8 \%$ & $12.9 \%$ \\
\hline Official “Creative” Public Sector & $-0.9 \%$ & $-1.6 \%$ & $2.2 \%$ & $3.1 \%$ & $22.7 \%$ \\
\hline
\end{tabular}




\begin{tabular}{|c|c|c|c|c|c|}
\hline Borrowing & & & & & \\
\hline $\begin{array}{l}\text { “Actual” Public Sector Borrowing } \\
\text { Requirements }\end{array}$ & $-0.7 \%$ & $-1.1 \%$ & $4.1 \%$ & $4.9 \%$ & $35.7 \%$ \\
\hline
\end{tabular}

Notes:

a. Total Government Spending = Primary Government Spending + Debt Services (interests and Amortizations)

b. Primary Government Spending = Social Spending (w/o Contributory Pensions $)+$ Non Social Spending (w/o Contributory Pensions) + Contributory Pensions

c. Social Spending $=$ Social Spending Incidence Benchmark + Other Social Spending

d. Social Spending Incidence Benchmark $=$ Cash Transfers (excluding Pensions) + Non-Contributory Pensions + Education + Health

e. Other Social Spending = Health Insurance for formal workers (Obras Sociales) + Health Insurance for formal workers retired (PAMI)+Social Assistance (Obras Sociales) + Social Assistance (PAMI)+Nutrition Program + Family Assignments + Other Federal, Provincial and Municipal Social Assistance Spending + Water and Sanitation + Housing + Other Urban Services + Culture (other Education)

f. Non Social Spending $=$ Indirect Subsidies + Other Non Social Spending

g. Other Non Social Spending $=$ Government Administration

Source: Authors' calculations based on Direccion Nacional de Gasto Publico, Ministry of Economy Argentina, ANSES and the methodology to impute moratorium pensions from the text. 
Table 2. Gini and headcount index for different income concepts: Argentina 2003, 2006, and 2009

\begin{tabular}{|c|c|c|c|c|c|c|c|c|c|}
\hline & \multicolumn{3}{|c|}{2003} & \multicolumn{3}{|c|}{2006} & \multicolumn{3}{|c|}{2009} \\
\hline & $\begin{array}{c}\text { Net } \\
\text { Market } \\
\text { Income }\end{array}$ & $\begin{array}{l}\text { Disposable } \\
\text { Income }\end{array}$ & $\begin{array}{l}\text { Final } \\
\text { Income }\end{array}$ & $\begin{array}{c}\text { Net } \\
\text { Market } \\
\text { Income }\end{array}$ & $\begin{array}{l}\text { Disposable } \\
\text { Income }\end{array}$ & $\begin{array}{c}\text { Final } \\
\text { Income }\end{array}$ & $\begin{array}{c}\text { Net } \\
\text { Market } \\
\text { Income }\end{array}$ & $\begin{array}{l}\text { Disposable } \\
\text { Income }\end{array}$ & $\begin{array}{l}\text { Final } \\
\text { Income }\end{array}$ \\
\hline \multicolumn{10}{|l|}{ Benchmark case ${ }^{b}$} \\
\hline Gini & 0.553 & 0.520 & 0.435 & 0.512 & 0.487 & 0.399 & 0.489 & 0.447 & 0.366 \\
\hline Effectiveness Indicator & & 3.0 & 2.9 & & 2.5 & 2.7 & & 2.3 & 2.1 \\
\hline \multicolumn{10}{|l|}{ Headcount index $(\%)$} \\
\hline$\$ 2.50 \mathrm{PPP} /$ day & $28.3 \%$ & $23.2 \%$ &.-- & $13.5 \%$ & $9.7 \%$ &.-- & $13.0 \%$ & $5.5 \%$ &.-- \\
\hline Effectiveness Indicator & & 9.0 & & & 14.4 & & & 15.6 & \\
\hline$\$ 4.00 \mathrm{PPP} /$ day & $41.5 \%$ & $38.2 \%$ &.-- & $22.7 \%$ & $18.8 \%$ &.-- & $21.9 \%$ & $14.4 \%$ &.-- \\
\hline Effectiveness Indicator & & 4.0 & & & 8.8 & & & 9.3 & \\
\hline Official National Extreme & $30.6 \%$ & $25.9 \%$ &.-- & $15.9 \%$ & $11.8 \%$ &.-- & $9.6 \%$ & $2.8 \%$ &.-- \\
\hline Effectiveness Indicator & & 7.7 & & & 13.2 & & & 19.1 & \\
\hline Official National Moderate & $56.5 \%$ & $54.7 \%$ &.-- & $38.3 \%$ & $35.5 \%$ &.-- & $22.6 \%$ & $15.7 \%$ &.-- \\
\hline Effectiveness Indicator & & 1.6 & & & 3.7 & & & 8.2 & \\
\hline FIEL National Extreme & $30.6 \%$ & $25.9 \%$ &.-- & $15.9 \%$ & $11.8 \%$ &.-- & $18.1 \%$ & $10.6 \%$ &.-- \\
\hline Effectiveness Indicator & & 7.7 & & & 13.2 & & & 11.2 & \\
\hline FIEL National Moderate & $56.5 \%$ & $54.7 \%$ &.-- & $38.3 \%$ & $35.5 \%$ &.-- & $36.1 \%$ & $30.6 \%$ &.-- \\
\hline Effectiveness Indicator & & 1.6 & & & 3.7 & & & 4.1 & \\
\hline
\end{tabular}

\section{Notes:}

a. Net market income equals market income minus income taxes and contributions to social security. b. All the indicators were calculated using the data on incomes from household surveys; they were not scaled-up to correspond to national accounts.

Source: Authors' calculations based on Encuesta Permanente de Hogares, 2003 2nd Semester, 2006 2nd semester, 2009 1st semester. 
Table 3. Contribution of Redistribution to Change in Disposable Income Inequality and Poverty

Gini

Change in Net Market Income Gini

Change in Disposable Income Gini

Change Attributable to Redistribution

Headcount index (US\$2.50 PPP/day)

Change in Net Market Income Poverty

Change in Disposable Income Poverty

Change Attributable to Redistribution

$\begin{array}{ccc}2009 / 2003 & 2006 / 2003 & 2009 / 2006 \\ -0.064 & -0.041 & -0.023 \\ -0.073 & -0.033 & -0.04 \\ -0.009 & 0.008 & -0.017 \\ 12.3 \% & -24.2 \% & 42.5 \% \\ & & \\ -0.153 & -0.148 & -0.005 \\ -0.177 & -0.135 & -0.042 \\ -0.024 & 0.013 & -0.037 \\ 13.6 \% & -9.6 \% & 88.1 \%\end{array}$

Source: Authors' calculations based on Encuesta Permanente de Hogares, 2003 2nd Semester, 2006 2nd semester, 2009 1st semester. 
Table 4. Concentration Coefficients and Budget Sizes for Selected Programs: Argentina 2003, 2006,

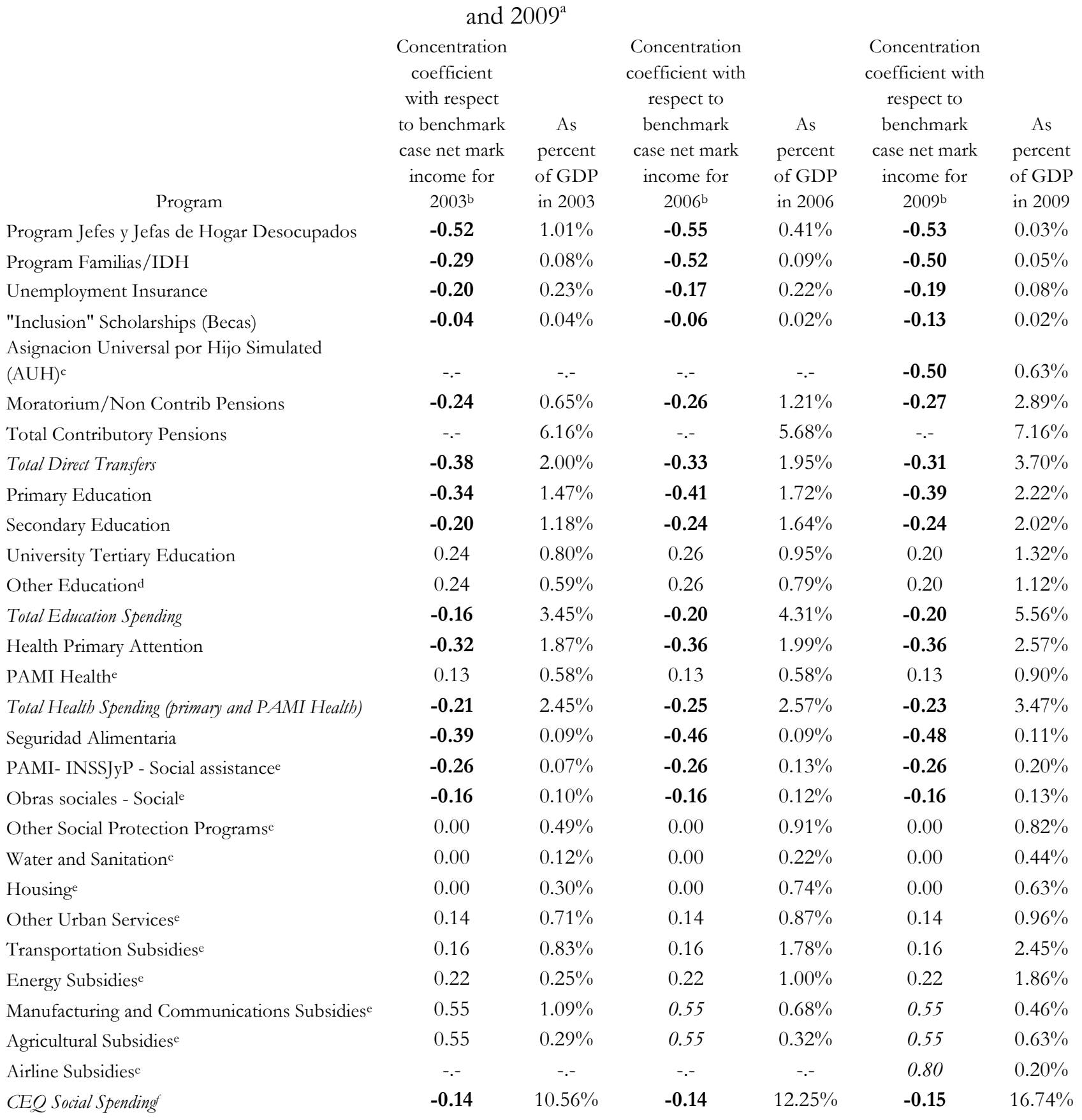

\section{Notes:}

a. By net market income original 
b. All the concentration coefficients are calculated by quintiles in this table. Concentration coefficients in bold are progressive in absolute terms, concentration coefficients in italics are regressive. All other concentration coefficients are progressive in relative terms.

c. In 2009, data on AUH is simulated (see the text) and the budget of JJHD and Familias is reduced if individuals in the simulation choose AUH and leave the other programs.

d. Total Education Spending does not include "other Education."

e. Indicates that the source of spending was not captured by EPH, and thus it was estimated from other sources. See Pessino (2010).

f. CEQ (Commitment to Equity) Social Spending includes spending on education, health, social assistance and the subsidized portion of social security.

Source: Authors' calculations based on Encuesta Permanente de Hogares, 2003 2nd Semester, 2006 2nd semester, 2009 1st semester, Direccion Nacional de Gasto Publico, Ministry of the Economy. 
Figure 1. Evolution of Social Assistance, Moratorium, and Contributory Pensions 2003-2009: Millions of Individuals

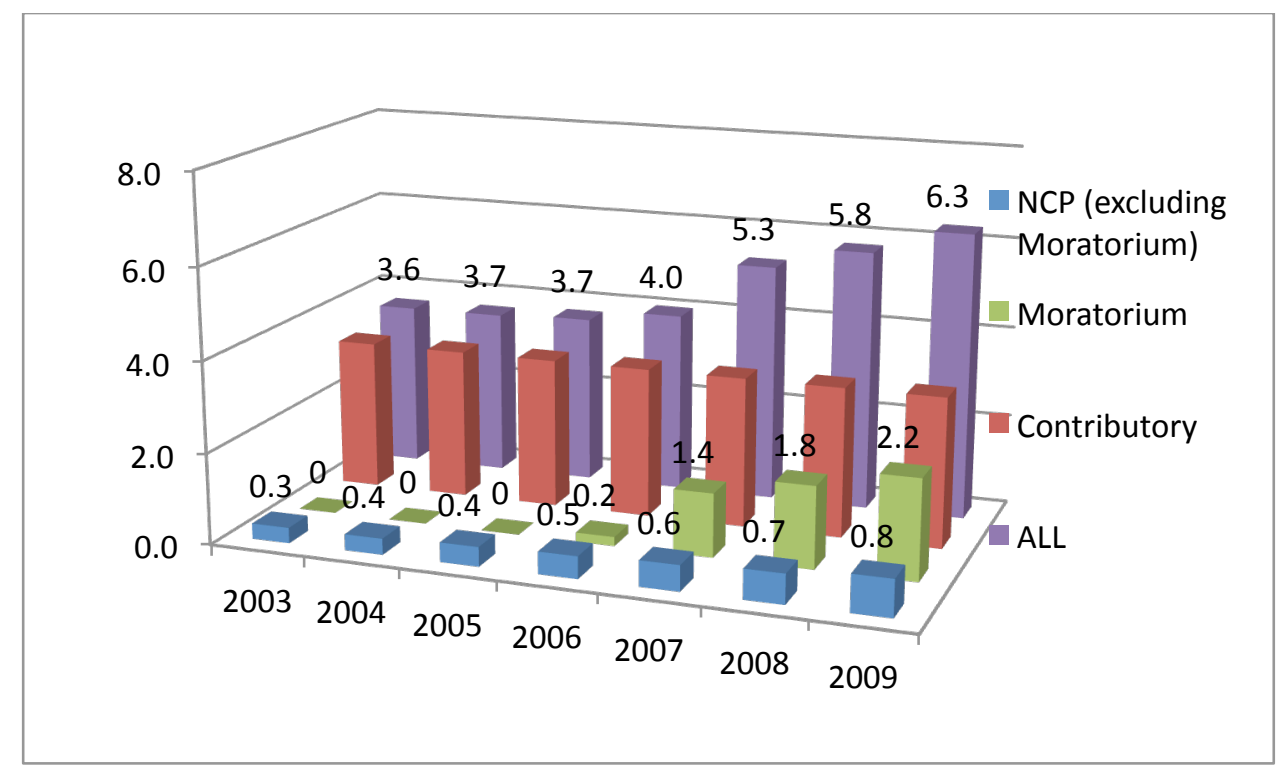

Source: Authors' calculations based on Chief of Cabinet of Ministers Memory to Congress (2009), and ANSES, Social Security Administration in Argentina. 
Figure 2. Percentage of People 65 and Older Receiving Any Kind of Pensions: 2003, 2006, and 2009

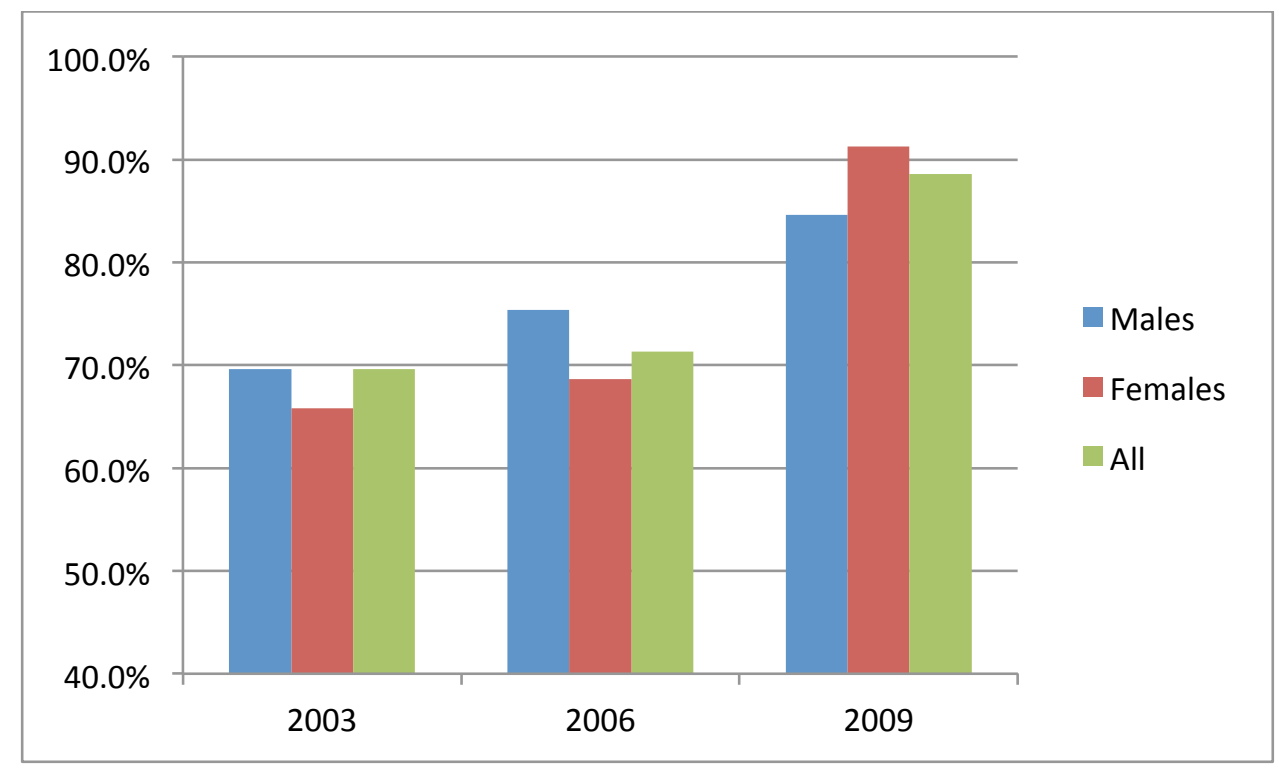

Source: Authors' calculations based on Encuesta Permanente de Hogares, 2003 2nd Semester, 2006 2nd semester, 20091 st semester. 
Figure 3. Percent of Poor Who are Beneficiaries

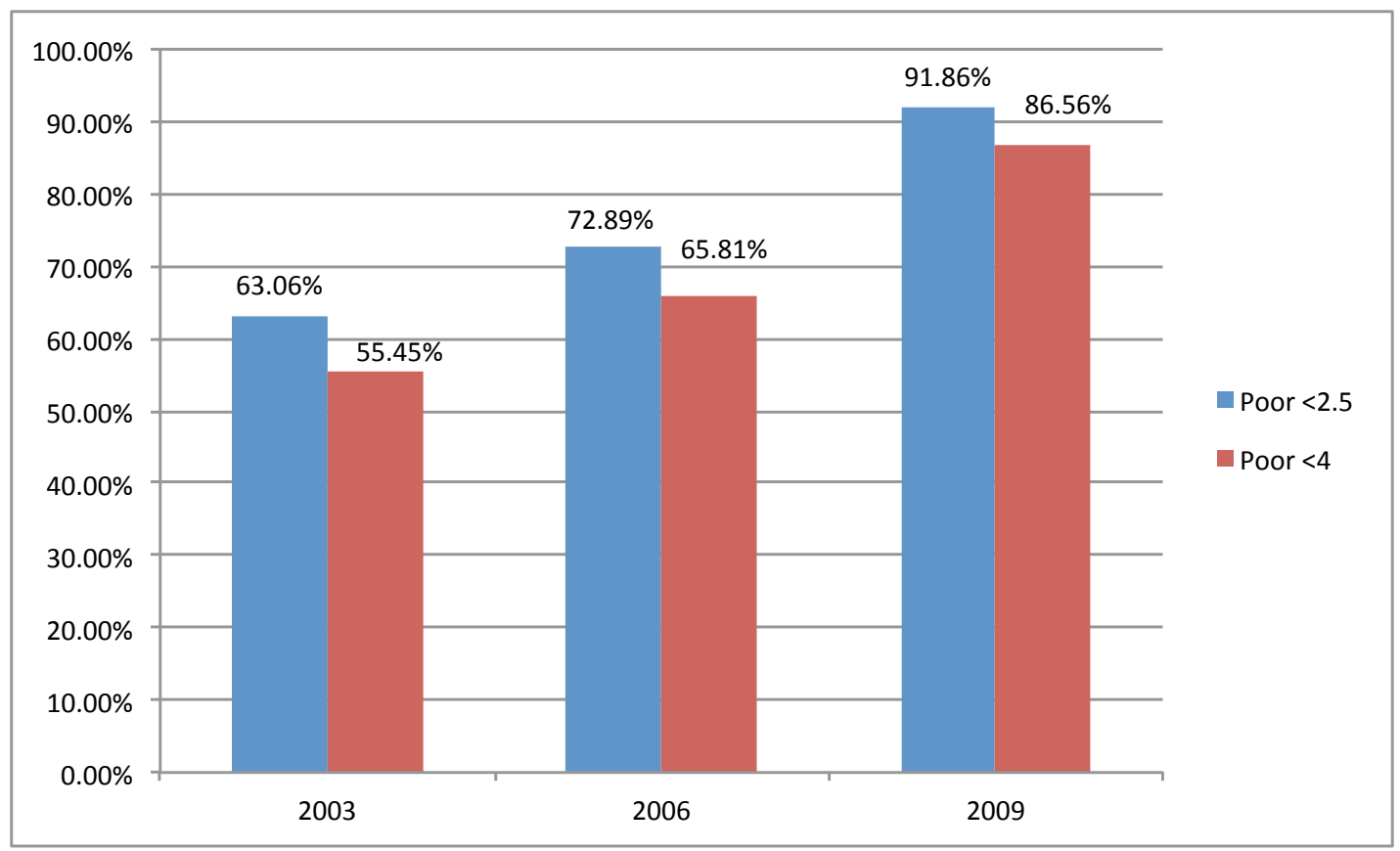

Source: Authors' calculations based on Encuesta Permanente de Hogares, 2003 2nd Semester, 2006 2nd semester, 2009 1st semester. 